\title{
A QUESTÃO SOCIAL E A LIBERDADE INDIVIDUAL SOCIEDADE CIVIL E EMANCIPAÇÃO INTEGRAL NOS ESTUDOS DO JOVEM KARL MARX'
}

Gianni Fresu

\begin{abstract}
RESUMO: O crescente interesse internacional pelo trabalho de Karl Marx durante a última década, que, não por acaso, coincide com a crise econômica mais grave do mundo desde 1929, está encorajando um florescimento de estudos em torno de seu trabalho, menos ligado às exigências da luta política imediata e mais atento ao entendimento científico de suas categorias e concepções mais representativas. Essa "Nouvelle Vague" dos estudos marxianos, com publicações e descobertas sem precedentes, colocou a exigência de novas abordagens metodológicas. Entre elas, a necessidade de considerar mais cuidadosamente as diferentes etapas da formação intelectual do caminho que marca a transição da crítica filosófica para a crítica da economia política pelo fundador e principal teórico do materialismo histórico. Nesse caminho, os primeiros escritos do jovem Marx, entre 1843 e 1844, representam uma passagem fundamental que, especialmente em Sobre a questão judaica, marcou sua descoberta da questão social, direcionando seus estudos e as perspectivas de seu pensamento para a necessidade da emancipação integral do homem.
\end{abstract}

Palavras-chave: Liberdade e igualdade, sociedade política e sociedade civil.

ABSTRACT: The growing international interest in Karl Marx's work over the last decade, which developed not by chance in coincidence with the world's most serious economic crisis since 1929, is encouraging a flourishing of studies around his work that is less tied to the demands of the immediate political struggle and more attentive to the scientific understanding of his most representative categories and conceptions. It is precisely this "Nouvelle Vague" of Marxian studies, which has led to unprecedented publications and discoveries, that has posed the need for new methodological approaches. Among these, the need to consider more carefully the different stages of the intellectual formation of the path that marks the transition from philosophical criticism to the criticism of political economy by the founder and major theoretician of historical materialism. Within this path, the first writings of the young Marx between 1843 and 1844 represent a fundamental passage which, especially in The Judaic Question, marked his discovery of the social question, directing his studies and the perspectives of his thought towards the need for the integral emancipation of man.

Keywords: freedom and equality, political society and civil society.

\footnotetext{
${ }^{1}$ Este trabalho representa o desenvolvimento orgânico de questões que abordei pela primeira vez no artigo "A questão judaica. A transição do jovem Marx da crítica filosófica à crítica da economia política”, (Revista Ideação, n. 39, jan./jun. 2019), fruto da leitura de novos estudos sobre Marx recentemente publicados.
} 


\section{Estudar Marx hoje}

Tratar o tema da emancipação integral do homem na obra do jovem Marx, afrontando a crítica dele à dimensão formal da igualdade no quadro das liberdades clássicas, assume hoje relevante valor político e científico, por duas razões: em primeiro lugar, porque estamos vivendo uma fase histórica marcada por uma profunda crise orgânica mundial, que não atinge apenas estruturalmente as formas de produção, acumulação e distribuição da riqueza, mas a própria hegemonia das classes dirigentes e das ideologias tradicionais, incluindo o sistema de representação parlamentar clássico; em segundo, porque, nesse contexto caracterizado pela instabilidade provocada pelas contradições do capitalismo mundial, estamos no meio de um renascimento dos estudos marxianos. Nesse sentido, Marcello Musto, autor que se destaca nessa área, no prefácio ao livro Marx revival, por ele organizado, salientou que desde a crise econômica que começou em 2008 Karl Marx "voltou à moda" graças a um interesse renovado que pode ser verificado em publicações em jornais, revistas e livros em paralelo com o florescimento dos estudos acadêmicos em homenagem ao pensador alemão e em torno das contradições do modo de produção capitalista. Entre os trabalhos de investigação científica, Musto também aponta o surgimento de um interesse crescente em aspectos até então desconhecidos da produção intelectual do filósofo de Trier, tais como aqueles sobre meio ambiente, gênero e etnias, ou sobre fenômenos migratórios relacionados com a dinâmica de expansão e exploração do capitalismo no mundo inteiro (MUSTO, 2019b, p. 11).

Como escreveu Giddens, em certo sentido, as obras de Marx abrangem uma temporada de três séculos. Ele nasceu quase vinte anos depois do início do século XIX e faleceu bem antes do fim do mesmo, todavia, seus escritos, por um lado, gozaram de máxima influência no curso do século seguinte, por outro, fincam suas raízes na última parte do século XVIII, nas grandes mudanças encaminhadas pela Revolução Francesa. As reflexões de Marx prolongam na idade contemporânea os efeitos daqueles acontecimentos, representando uma linha de continuidade entre a Revolução de 1789 e a do outubro de 1917 revolução (GIDDENS, 1991, p. 27). Além das avaliações subjetivas a respeito da validade ou não de 
seu pensamento, o sucesso e a difusão internacional do legado de Marx são um fato indiscutível:

Da América Latina ao Extremo Oriente, nas sedes sindicais mais pobres da periferia ou nas aulas magnas das universidades mais prestigiadas, dezenas e dezenas de milhões de trabalhadoras e trabalhadores e de jovens estudantes leram seus escritos. Deles extraíram a consciência de sua condição de oprimidos e, com o tempo, ganharam inspiração para promover novos conflitos, organizando greves, movimentos sociais e partidos políticos. Lutaram por pão e por rosas, contra a injustiça e pela liberdade e, assim fazendo, deram plena atualização às teorias de Marx. (MUSTO, 2018b, p. 135-136).

\section{As primeiras etapas de um longo percurso intelectual}

Para adentrar nesse caminho, é preciso lembrar que o jovem Marx mergulhou na filosofia de Hegel depois de ter largado sua paixão inicial pela poesia e pelos estudos jurídicos, tomando consciência da pouca satisfação que lhe suscitou a leitura da obra de Fichte e de Kant. Todavia, suas primeiras abordagens da obra de Hegel já foram bem pouco ortodoxas e mediadas pelo interesse pelo debate sobre o nascente socialismo utopista (GIDDENS, op. cit., p. 28). Marx filiou-se ao Doktorklub (Clube dos doutores) da Universidade de Berlim, onde entrou em contato com o grupo heterogêneo dos jovens hegelianos, em que Bruno Bauer era a figura mais carismática² . Como na dissertação doutoral, que comparava a filosofia de Demócrito à de Epicuro, também no primeiro trabalho do jovem Marx, a Crítica da filosofia do direito de Hegel, encontramos forte influência de Bauer. Em contrapartida, em Sobre a questão judaica, escrito no outono de 1843 e publicado nos Anais Franco-Alemães" de fevereiro de 1844, Marx polemiza com Bauer, afirmando que a completa emancipação do homem não pode limitar-se à emancipação política, precisaria atingir as relações sociais e produtivas. Isso também se verifica na Introdução à Crítica da filosofia do direito, escrita para os Anais Franco-Alemães no final do 1843 e publicada em fevereiro de 1844, na qual encontramos o abandono definitivo da crítica religioso-política pura e simples e os primórdios da crítica social marxiana. Em Sobre a questão judaica e na

\footnotetext{
${ }^{2}$ A propósito, ver: MOGGAH, 2003; ROSEN, 1977.
} 
Introdução, Marx se emancipa completamente da influência de Bauer; portanto, na passagem de 1843 para 1844, essas três etapas representam momentos essenciais na formação da visão filosófica do jovem Marx. A partir da Crítica da filosofia do direito de Hegel, com a qual ele estabeleceu a convicção de que a sociedade civil é a verdadeira base da sociedade política, Marx começou a desenvolver suas primeiras formulações sobre a relevância da economia em todas as relações sociais. Mas foi sobretudo em Paris, quando entrou em contato com o proletariado e graças à influência exercida pelos primeiros escritos de Engels, que ele mergulhou no estudo da economia política. O encontro com Engels, que infundiu em Marx o interesse pela economia política e pela história econômica, foi, portanto, fundamental na vida do filósofo de Trier (tanto no plano teórico quanto no humano). Entre 1842 e 1844, quando estava na Inglaterra para trabalhar na filial inglesa da empresa do pai, Engels conheceu diretamente as dinâmicas da sociedade capitalista e começou a estudar a economia política clássica, sintetizando suas reflexões críticas sobre as características daquela formação econômico-social no ensaio "Esboço de uma crítica da economia política" (publicado nos Anais Franco-Alemães em fevereiro de 1844) que impressionou muito favoravelmente Marx. A confirmação desse interesse pelas investigações econômicas de Engels se encontra nas notas dos Manuscritos econômicofilosóficos onde é possível localizar várias referências ao texto de Engels. Na evolução de Marx da crítica filosófica a crítica da economia política o papel de Engels é central - ainda que alguns estudiosos subestimem ou omitam essa centralidade, chegando mesmo a considerá-lo o primeiro profanador da obra marxiana. A partir dessa mudança, temos a transição das investigações filosóficas e históricas para os problemas científicos despertados em Marx pela investigação da economia e pela observação cuidadosa do que acontece na vida real e cotidiana da sociedade capitalista (MUSTO, 2018a, p. 5).

A perspectiva de Marx engendra a exigência de tornar possível o pleno desenvolvimento da personalidade humana, pela superação das condições impostas pela divisão de classes e pela especialização do trabalho. É com os Manuscritos econômico-filosóficos (escritos entre março e agosto de 1844) que Marx começa o estudo da econômica política clássica, aprofundando a leitura da obra de Smith e de Ricardo e chegando, dessa maneira, à definição essencial do materialismo histórico. Um estudioso como David McLellan, chega 
a definir os textos anteriores a essa virada de "estudos pré-marxistas", no sentido de que neles ainda não encontramos nenhuma interpretação da história em termos de classes, modos de produção e análise da relação entre capital e trabalho (MCLELLAN, 1978, p. 37). Uma afirmação excessiva, talvez provocativa, porque não considera quanto a passagem da Critica da filosofia do direito de Hegel a Para a questão judaica seja fundamental para o surgimento de algumas das principais categorias do materialismo histórico.

Ao longo de sua vida intelectual, Marx manteve uma enorme quantidade de cadernos onde anotou estudos, comentários às leituras, rascunhos e reflexões sobre os diferentes temas por ele abordados (primeiramente, filosofia, política, economia e história). Nesses cadernos, Marx guardava conceitos e raciocínios para projetos que planejava desenvolver. No período em que viveu em Paris (entre outubro de 1843 e fevereiro de 1845), ele escreveu o que os estudiosos chamam de Cadernos parisienses, um conjunto de notas onde se encontram os fundamentos da Crítica da filosofia do direito, d'A sagrada família e de vários artigos publicados naqueles anos. É desse material que, entre 1927 e 1932, se extraíram também os chamados Manuscritos econômico-filosóficos de 1844, publicados na União Soviética e na Alemanha. Portanto, esse trabalho, obra muito conhecida e estudada, não é um livro propriamente dito, mas o resultado da transcrição dos três cadernos que Marx elaborou entre maio e agosto de 1844. A publicação desse material, definido como "ensaios fragmentários", e também de outros inéditos, foi resultado dos estudos feitos nos arquivos pelo diretor do Instituto Marx-Engels de Moscou David Riazánov (1870-1938) (DONAGGIO, 2018).

Segundo Ellen Meiksins Wood, a crítica de Marx à democracia burguesa é dirigida sobretudo a seu conteúdo puramente formal, que tornaria irrealista e limitada a uma pequena porção da humanidade a chamada transição da necessidade para o reino da liberdade. Entretanto, Wood enfatizou a parcialidade e a incompletude desse aspecto para compreender integralmente a crítica de Marx:

A afirmação de que os processos políticos na "democracia burguesa" são, para melhor ou para pior e em maior ou menor grau, condicionados pelas desigualdades de classe é de fato difícil de desafiar, mas mal é suficiente para distinguir o marxismo de outras 
interpretações do mundo em que a democracia liberal funciona nas sociedades capitalistas marcadas por enormes desigualdades de riqueza. (WOOD, 2019, p. 60, tradução nossa).

A "grande intuição de Marx" não se limita à crítica da contradição entre liberdade formal e desigualdade substancial, nem sua abordagem pode ser confundida com falta de interesse ou mesmo hostilidade em relação aos direitos fundamentais, fruto das revoluções burguesas; ao contrário, ele incitava constantemente o movimento operário a lutar por elas e a expandi-las:

Seu socialismo nasceu da crescente consciência de que as liberdades que ele procurava defender exigiam mais do que formas jurídicas democráticas e direitos políticos desligados da realidade do poder social. Nem, por outro lado, era sua intenção demonstrar simplesmente que os efeitos políticos da desigualdade eram na verdade piores do que pareciam. A força de suas críticas deve ser encontrada em outro lugar. (Ibid., p. 61-62, tradução nossa).

De acordo com Wood, ainda mais do que em seus escritos explicitamente políticos, uma crítica mais direta aos limites da democracia liberal pode ser encontrada nos estudos de Marx sobre as críticas à economia política. Em uma sociedade caracterizada pelo alto desenvolvimento de suas forças produtivas, a relação orgânica entre o poder político e a dimensão econômica exige uma redefinição do conceito de democracia, não apenas para intervir nas desigualdades, mas também para ampliar a esfera dos direitos fundamentais e dos direitos ligados à cidadania de uma sociedade democrática.

No início de sua formação, o principal impulso do jovem Marx foi defender as liberdades civis, antes de tudo a liberdade de imprensa e de opinião, contra a interferência do poder despótico. A impossibilidade de empreender uma carreira acadêmica, devido a suas posições radicais, empurrou-o para o jornalismo com o grupo de jovens hegelianos empenhados nas atividades organizadas por Arnold Ruge, dirigindo suas crônicas críticas (nos Anais Franco-Alemães e sobretudo na Gazeta Renana) à natureza conservadora e autoritária das instituições prussianas (PETRUCCIANI, 2009, p. 9).

Entretanto, mesmo mais tarde, Marx não abandonou a convicção sobre a necessidade de o proletariado conquistar e defender as chamadas liberdades burguesas, por mais que criticasse seus limites. A descoberta da questão social, porém, evou-o a investigar a 
inadequação dos direitos políticos quando considerados na dimensão puramente abstrata da cidadania, que ignorava a contradição gerada pela desigualdade econômica. Nesse sentido, Sobre a questão judaica esclarece a intenção de ir além da concepção política baseada na oposição entre sociedade civil e sociedade política presente na Filosofia do direito de Hegel, mostrando a contradição entre a representação idealizada do Estado como uma universalidade absoluta e neutra acima da sociedade civil e a substância concreta das relações sociais da qual a sociedade política era expressão orgânica (WOOD, 2019, p. 67).

\section{A questão judaica}

$\mathrm{Na}$ Alemanha do início do século XIX, ainda existiam restrições legais que limitavam os direitos civis dos judeus, excluídos das profissões públicas da administração - o pai de Marx, por exemplo, foi constrangido à conversão religiosa para exercer a atividade de advogado. Essa limitação, no curso daquela década, levou a uma dura disputa entre conservadores e progressistas: os primeiros, partidários da defesa da natureza confessional do Estado alemão; os segundos, favoráveis à plena liberdade religiosa e à inclusão dos judeus (sem mais limitações) na esfera dos direitos civis. Esse argumento foi afrontado por Bruno Bauer em alguns escritos entre 1842 e $1843^{3}$. Segundo Bauer, era a natureza cristã do Estado a tornar contraditória a emancipação jurídica dos judeus, que, para adquirir a plena cidadania, deviam reconhecer uma realidade institucional alicerçada nos privilégios dos cristãos. Por um lado, o judeu, permanecendo vinculado à própria religião, só poderia viver separado do resto da sociedade, por outro, o cristão, enquanto cristão, não poderia conceder plenos direitos de cidadania aos judeus. Portanto, mais do que aspirar à emancipação particular, os judeus deviam lutar para a emancipação universal, libertandose dos grilhões do judaísmo. Todavia, segundo ele, os judeus não lutavam para afirmar o Estado laico, mas apenas para obter o reconhecimento do particularismo religioso deles por parte do Estado cristão. A emancipação possível dos judeus não deveria implicar a eliminação dos limites ao exercício da própria profissão religiosa, mas a emancipação tanto do cristianismo quanto do judaísmo, ou seja, a completa libertação dos vínculos religiosos enquanto tais. $\mathrm{Na}$ passagem ao ateísmo estava a premissa para a plena emancipação

\footnotetext{
${ }^{3}$ Ver BAUER, MARX, 2004, p. 41-101.
} 
política, portanto, segundo Bauer, eles deveriam juntar-se aos outros cidadãos alemães na luta pelos direitos democráticos. Enquanto persistir o Estado confessional, não poderá existir nenhuma liberdade, nem para os cristãos nem para os judeus. O erro estava na reivindicação de um interesse particular, quando era preciso lutar para a afirmação do direito universal da igualdade entre os homens. A emancipação universal só poderia se dar pela liberação do Estado do particularismo de qualquer vínculo religioso, isso teria favorecido o desaparecimento das próprias religiões e a emancipação integral dos homens dos grilhões místicos.

Contra essa posição, Marx apontou algumas contradições da visão de Bauer, criticando a ilusão da emancipação humana apenas na esfera política. Polêmica que depois encontramos também nos estudos para $A$ ideologia alemã, já na primeira página dos rascunhos sobre "Feuerbach e história" (que originalmente deviam tornar-se um artigo intitulado "Crítica da 'Caracterização de Ludwig Feuerbach', de Bruno Bauer"), em que Marx polemiza com os jovens hegelianos. Eles estavam convencidos de ter produzido um progresso filosófico até "a libertação do homem", mas, pelo contrário, reduziram "a filosofia, a teologia, a substância e todo esse lixo à 'autoconsciência'” (MARX, ENGELS, 2007, p. 29). Segundo Marx,

só é possível conquistar a libertação real no mundo real e pelo emprego de meios reais; [...] a escravidão não pode ser superada sem a máquina a vapor e a Mule-Jenny [máquina de fiar criada na Inglaterra em 1779 por Samuel Crompton], nem a servidão sem o progresso da agricultura, e que, em geral, não é possível libertar os homens enquanto estes forem incapazes de obter alimentação e bebida, habitação e vestimenta, em qualidade e quantidade adequadas. [...] para o materialista prático, isto é, para o comunista, trata-se de revolucionar o mundo, de enfrentar e de transformar praticamente o estado de coisas por ele encontrado. (Ibid., p 29-30, grifos do original).

Em Sobre a questão judaica, Marx sublinhou como Bauer assumiu acriticamente a representação hegeliana do Estado, considerado uma entidade ética acima das partes em conflito, que age para conciliar o particular com o universal. Diferentes concepções sobre o papel do Estado e a esfera da sua atividade perante a sociedade civil marcam a luta política no Ocidente desde o século XVIII até hoje. O liberalismo sempre considerou o 
Estado uma entidade neutral e universal acima das partes em luta, que harmoniza o interesse particular com aquele geral, limitando-se a estabelecer as regras e a fazer que sejam respeitadas para garantir a autonomia e a independência da sociedade civil e defender a esfera da individualidade das intromissões políticas ${ }^{4}$. Dentro dessa tradição, John Rawls não apenas acredita na neutralidade dos aparelhos fundamentais das modernas sociedades democráticas, ele acha que só garantindo esse agnosticismo das instituições fundamentais torna-se possível o pluralismo razoável. Como sabemos, Rawls tentou definir uma noção liberal eficaz de justiça para indicar procedimentos mais adequados para compreender como nossas instituições podem ser mais democráticas. O liberalismo igualitário de Rawls, problematicamente atento à questão da igualdade e da igualdade de oportunidades, retomou e desenvolveu as questões centrais da histórica dialética entre filosofia liberal e pensamento democrático. Olhando para as modernas sociedades alicerçadas no pluralismo razoável, Rawls localizou o ponto de mediação mais eficaz das duas tradições numa concepção política capaz de conjugar de forma harmônica a ideia de justiça com as categorias da liberdade em suas duas declinações (negativa e positiva). Essa mediação, entretanto, parte do reconhecimento da centralidade das liberdades políticas, recusando a ideia segundo a qual o liberalismo esgotaria seu papel ao garantir a liberdade de iniciativa econômica diante da interferência do Estado. Rawls considera negativamente essa linha de pensamento liberal que, de Constant até o neoliberalismo de Mises e Von Hayek, subestima o papel das liberdades políticas até localizar nelas um potencial perigo para a liberdade negativa. $\mathrm{Na}$ realidade, segundo Rawls, somente através do exercício pleno da liberdade positiva, ou seja, por meio do controle a partir de baixo exercido pelos cidadãos, é possível defender e fortalecer as liberdades individuais. Da mesma forma, só se a liberdade negativa é considerada sagrada e não contratável, também a liberdade positiva pode desenvolver-se organicamente e sem

\footnotetext{
4 “Assim, se um regime constitucional tomar certas medidas para fortalecer as virtudes da tolerância e da confiança mútua, desencorajando, por exemplo, os vários tipos de discriminação religiosa e social (de forma coerente com a liberdade de consciência e expansão), não se transformaria por isso num Estado perfeccionista do tipo encontrado em Platão ou Aristóteles, nem estabelece uma religião específica, como nos Estados católicos e protestante do início do período moderno. Está, em vez disso, tomando medidas razoáveis para fortalecer as formas de pensar e sentir que sustentam a cooperação social equitativa entre seus cidadãos considerados livres e iguais. Isso é muito diferente de o Estado promover uma determinada doutrina abrangente em seu próprio nome." (RAWLS, 2000, p. 243).
} 
condicionamentos externos. Por sua vez, reconhecer o valor da justiça além da sua dimensão puramente formal, garantindo com a igualdade de oportunidades uma completa mobilidade social, não seria uma limitação das liberdades fundamentais clássicas, mas uma extensão que limita os perigos de uma cristalização oligopolista da sociedade. Para que uma sociedade dê prioridade às liberdades, considerando-as como o verdadeiro objetivo final da cooperação, deve haver condições favoráveis, ou seja, as circunstâncias sociais necessárias para que a vontade política introduza as liberdades prioritárias. Essas condições são determinadas pela cultura de uma sociedade, suas tradições, as habilidades adquiridas através do bom funcionamento de suas instituições e o desenvolvimento econômico harmonioso de suas forças produtivas. Essas condições são encontradas nas sociedades democráticas modernas, tornando possível a plena implementação das liberdades fundamentais. A proteção institucional dessas liberdades, ou seja, o fato de serem consideradas a razão do acordo político constitucional, é um pré-requisito para o desenvolvimento adequado e o pleno exercício dos poderes morais dos cidadãos como pessoas livres e iguais. Sob condições razoavelmente favoráveis, as liberdades fundamentais são compatíveis umas com as outras e podem encontrar um ponto de mediação. A existência de liberdades fundamentais e bens fundamentais que tornam possível o desenvolvimento pleno e livre da personalidade do indivíduo precisa de ser incorporada a uma estrutura constitucional capaz de funcionar. A conclusão de Rawls é que a experiência histórica nos mostra nas constituições democráticas o modelo mais eficaz para garantir um sistema completo de liberdades efetivas e, enquanto tais, praticáveis.

Voltando a Sobre a questão judaica, segundo Marx, Bauer, por um lado, exige que o judeu largue o judaísmo e, no plano geral, que o homem abandone a religião para tornar-se um ser civilmente emancipado; por outro, ele acredita que a superação política da religião seria equivalente à abolição da religião enquanto tal e à afirmação de um Estado moderno e completo. Marx localiza exatamente nesse ponto a primeira contradição do raciocínio de Bauer: quando ele afirma que é preciso indagar a espécie de emancipação da qual falamos e as suas condições implícitas, concluindo que "a crítica à emancipação política mesma poderia constituir a crítica definitiva à questão judaica e sua verdadeira dissolução na 
"questão geral da época'" (MARX, 2010, p. 36, grifos do original)., Bauer coloca questões que não são implícitas à essência da emancipação política. Ele aponta suas críticas apenas sobre o Estado cristão, não contra o Estado em geral, dessa maneira, não investiga o eixo entre emancipação humana e emancipação política e levanta, assim, condições que se explicam apenas em razão da confusão analítica na abordagem desses dois níveis. A emancipação política da qual fala Bauer não corresponde à emancipação real, isso é confirmado historicamente pelo exemplo concreto da democracia estadunidense, um Estado que formalmente não tem natureza confessional, mas no qual, todavia, como confirma Tocqueville, o espírito religioso permeia cada aspecto da vida social e política. Assim, a Revolução Americana fez referência explícita ao "Criador" e à lei "divina", além da "natural", apesar de não assumir diretamente natureza confessional.

A emancipação do Estado da religião não corresponde à emancipação humana e não coincide com sua completa liberdade, isso significa que, apesar da natureza laica ou confessional, a contradição é imanente ao Estado enquanto tal, às relações sociais das quais ele é expressão orgânica (ibid., p. 38-40). O fato de que Estado se emancipe da religião não significa que a maioria dos cidadãos se libertem da religião, exatamente porque o primeiro progresso não significa a emancipação plena e a superação das contradições que caracterizam a sociedade. A religião torna-se algo puramente privado, mas nem por isso deixa de ser atividade religiosa. O homem se liberta por meio do Estado (politicamente) de uma barreira achando-se em contradição consigo mesmo. Trata-se apenas de um subterfúgio através de um meio (o Estado), mesmo que necessário. Para evitar equívocos, Marx não afirma que a secularização do Estado é supérflua, ele a considera um progresso, mesmo reafirmando que seria pura ilusão considerar essa emancipação política da teologia uma libertação do homem dos seus grilhões. Não é a última etapa da emancipação humana em geral, mas a derradeira etapa da emancipação humana dentro do contexto do mundo atual. Marx quer ampliar o discurso, falando da "emancipação real, a emancipação prática" (ibid., p. 41.

Decorre, por fim, que, mesmo proclamando-se ateu pela intermediação do Estado, isto é, declarando o Estado ateu, o homem continua religiosamente condicionado, justamente 
porque ele só reconhece a si mesmo mediante um desvio, através de um meio. A religião é exatamente o reconhecimento do homem mediante um desvio, através de um mediador. O Estado é o mediador entre o homem e a liberdade do homem. [...] A elevação política do homem acima da religião compartilha de todos os defeitos e de todas as vantagens de qualquer elevação política. (Ibid., p. 39, grifos do original).A acusação que Marx dirige a Bauer é de que ele nunca saiu da representação ilusória do Estado feita por Hegel, como entidade acima das partes que junta o interesse particular com o universal, porque nunca abordou sua dimensão material. Novamente, como já aconteceu na Crítica da filosofia do direito de Hegel, encontramos a crítica à concepção hegeliana do Estado e sua representação das relações entre ele e a sociedade civil. Na dimensão ilusória do Estado político, a vida do indivíduo assume o mesmo significado irreal da dimensão religiosa. Enquanto na sociedade civil o egoísmo orienta as atividades humanas no rumo do particularismo, no Estado, como na religião, pelo contrário o homem teria a ilusão de ser parte de uma dimensão universal.

O Estado político pleno constitui, por sua essência, a vida do gênero humano em oposição à sua vida material. Todos os pressupostos dessa vida egoísta continuam subsistindo fora da esfera estatal na sociedade burguesa, só que como qualidades da sociedade burguesa. Onde o Estado político atingiu a sua verdadeira forma definitiva, o homem leva uma vida dupla não só mentalmente, na consciência, mas também na realidade, na vida concreta; ele leva uma vida celestial e uma vida terrena, a vida na comunidade política, na qual ele se considera um ente comunitário, e a vida na sociedade burguesa, na qual ele atua como pessoa particular, encara as demais pessoas como meios, degrada a si próprio à condição de meio e se torna um joguete na mão de poderes estranhos a ele. A relação entre o Estado político e a sociedade burguesa é tão espiritualista quanto a relação entre o céu e a terra. A antítese entre os dois é a mesma, e o Estado político a supera da mesma maneira que a religião supera a limitação do mundo profano, isto é, sendo igualmente forçado a reconhecê-la, produzi-la e deixar-se dominar por ela. Na sua realidade mais imediata, na sociedade burguesa, o homem é um ente profano. Nesta, onde constitui para si mesmo e para outros um indivíduo real, ele é um fenômeno inverídico. No Estado, em contrapartida, no qual o homem equivale a um ente genérico, ele é o membro imaginário de uma soberania fictícia, tendo sido privado de sua vida individual real e preenchido com uma universalidade irreal. $\mathrm{O}$ conflito que emerge entre o homem 
que professa uma religião particular e sua cidadania, entre ele e as demais pessoas como membros da sociedade, reduz-se à divisão secular entre o Estado político e a sociedade burguesa. (Ibid., p. 40-41, grifos do original).

$\mathrm{Na}$ moderna dimensão do Estado burguês, a vida política torna-se apenas uma exceção momentânea e aparente à regra geral que marca a vida humana, exatamente como antes acontecia com a dimensão religiosa em relação à vida cotidiana. Então, a diferença entre o homem religioso e o cidadão é idêntica àquela entre o comerciante e o cidadão, o trabalhador e o cidadão, o latifundiário e o cidadão, ou seja, entre o indivíduo que vive e o cidadão. A contradição que existe entre o homem religioso não é diferente daquela entre o burguês e o cidadão.

Bauer, segundo Marx, simplifica a luta secular entre o Estado político e suas premissas, tanto os elementos materiais (a propriedade privada) quanto aqueles espirituais (cultura e religião), desconhecendo a luta entre o interesse geral e o interesse particular, ou seja, "a divisão entre o Estado político e a sociedade burguesa" (ibid., p. 41, grifos do original), limitando-se a polemizar com a sua expressão religiosa.

O homem se emancipa politicamente da religião, banindo-a do direito público para o direito privado. Ela não é mais o espírito do Estado, no qual o homem - ainda que de modo limitado, sob formas bem particulares e dentro de uma esfera específica - se comporta como ente genérico em comunidade com outros homens; ela passou a ser o espírito da sociedade burguesa, a esfera do egoísmo, do bellum omnium contra omnes [da guerra de todos contra todos]. (Ibid., p. 4142 , grifos do original).

\section{Religião e emancipação}

Segundo Marx, quando a religião torna-se atividade apenas da esfera privada, quando deixa o Estado para ser exclusiva da sociedade civil, temos a emancipação política do Estado em relação à religião. Isso não significa, entretanto, a superação da religião, aliás, sem a resolução das contradições sociais na base da sociedade, pode ser o exato contrário. O Estado cristão perfeito não é o chamado Estado cristão que reconhece no cristianismo seu fundamento e sua religião estatal de forma exclusiva e excludente perante as outras religiões. O Estado cristão perfeito é o Estado ateu, democrático, que relega a religião à sociedade civil. O Estado confessional é, segundo Marx, um Estado ainda incompleto, que 
utiliza instrumentalmente a religião apenas como meio de legitimação, sem transformar, por isso, a religião no efetivo fundamento da vida social acima da qual se eleva o Estado. Trata-se do Estado da hipocrisia.

O assim chamado Estado cristão nada mais é do que o não Estado, porque o que nele pode efetuar-se, em termos de criação realmente humana, não é o cristianismo como religião, mas tão somente o pano de fundo humano da religião cristã. $\mathrm{O}$ assim chamado Estado cristão constitui, na verdade, a negação cristã do Estado, mas jamais a realização estatal do cristianismo. [...] O assim chamado Estado cristão é o Estado incompleto, e ele tem a religião cristã na conta de complemento e santificação de sua incompletude. [...] $\mathrm{O}$ assim chamado Estado cristão necessita da religião cristã para completar-se como Estado. O Estado democrático, o Estado real, não necessita da religião para chegar à sua completude política. Ele pode, antes, abstrair da religião, porque nele se realiza efetivamente em termos seculares o fundamento humano da religião. $\mathrm{O}$ assim chamado Estado cristão, em contrapartida, comporta-se politicamente para com a religião e religiosamente para com a política. Ao rebaixar as formas estatais à condição de aparência, ele rebaixa na mesma proporção a religião a essa condição. (Ibid. p. 4243 , grifos do original).

Pelo contrário, a secularização torna o espírito religioso verdadeiro fundamento da vida social, exatamente porque não precisa mais de um Estado guardião da Igreja. "O fundamento desse Estado não é o cristianismo, mas o fundamento humano do cristianismo. A religião permanece a consciência ideal, não secular de seus membros, porque é a forma ideal do estágio de desenvolvimento humano, que nela efetivamente é realizado" (ibid., p. 45). Paradoxalmente, na crítica à filosofia de Bauer, Marx volta à lição de Hegel, o qual, na Filosofia da história, explicou o processo que, pelo impulso da reforma religiosa, levou tanto à legitimação do Estado quanto à afirmação da religião como interioridade. Nesse devir (que antes passa pelas etapas do mundo oriental, daqueles grego e romano), o fim do espírito germânico e a Reforma de Lutero seriam a realização da verdade absoluta como infinita autodeterminação da liberdade e sustento do princípio cristão, nesse sentido ele o define como o "espírito do mundo moderno".

Na Filosofia da história temos três períodos históricos desse mundo caracterizados por três elementos essenciais: o surgimento das nações germânicas; a oposição entre Igreja e 
Estado; a Reforma religiosa. Hegel descreve esses períodos como os reinos do Pai, do Filho e do Espírito: "O do Pai é a massa substancial indivisível, em transição, como o domínio de Saturno que engole os seus filhos. O reino do Filho é o surgimento de Deus somente em relação à existência temporal, refletindo-se nela como algo alheio. O reino do Epírito é a reconciliação" (HEGEL, 1995, p. 293). O primeiro vai do nascimento dos povos germânicos no seio do Império Romano e do cristianismo até a idade de Carlo Magno, uma fase não particularmente interessante porque caracterizada pela selvageria e inocência desses povos, "surge, então, o mundo cristão como cristianismo, como uma massa, na qual o espiritual e o temporal são apenas diferentes facetas" (ibid., p. 292).

O segundo é caraterizado por uma dialética que desenvolve essas duas facetas até uma consequente autonomia do poder temporal. A aliança entre Carlo Magno (coroado imperador pelo próprio papa) e a Santa Sé contra os partidos aristocráticos de Roma determinou uma estrita ligação entre poder temporal e poder espiritual, mas, apesar disso, segundo Hegel, é exatamente nessa época que começa a desenvolver-se a interioridade do espírito cristão "voltado para o exterior e fora de si". Novamente emerge a visão dialética do filósofo alemão, que localiza na negação dos valores do cristianismo a origem de uma mais profunda e interior espiritualidade religiosa. Isso porque a liberdade cristã se transformou em servidão, tanto no plano religioso, quanto naquele temporal, "na mais cruel imoralidade, na desordem e nas brutalidades de todas as paixões". São dois os elementos principais dessa fase:

O primeiro é a formação dos Estados, que se apresentam numa subordinação da obediência tal que tudo se torna um direito fixo particular, sem o sentido da universalidade. Essa subordinação da obediência aparece no sistema feudal. O segundo aspecto é a oposição entre a Igreja e o Estado. Ela existe porque a Igreja deveria administrar o sagrado, rebaixa-se ao temporal, e assim este poder mostra-se de uma maneira mais desprezável, porque todas as paixões encontram a justificativa na religião. (Ibid.).

A partir dessa contradição determina-se o conflito que marca dramaticamente a cristandade na primeira metade do século XVI. O conflito entre o Império de Carlo V e a Santa Sé, que chegou até a conquista e a destruição da capital da cristandade pelas tropas do imperador em maio de 1527, teve origem no confronto entre os dois poderes e na luta 
pelo predomínio entre eles. Por um lado, a Igreja defendia o próprio poder temporal e sua integridade territorial, sem renunciar às suas ingerências nas funções imperiais (ainda mais com a Reforma Protestante); por outro, Carlo V pretendia o apoio da Igreja católica a seus planos de império universal sobre a Europa. Exatamente nessa temporada ensanguentada por guerras e horrores começa o terceiro período do mundo germânico, fundamental tanto no plano espiritual, com a Reforma luterana, quanto naquele temporal, com a afirmação do Estado moderno secularizado, que se emancipa do vínculo religioso e da legitimação espiritual da sua autoridade. O Estado objetiva o espírito universal chegando à completa consciência de si, de seu próprio direito e da própria moralidade objetiva, reivindicando sua legalidade, sua integridade e a atividade do homem:

Surge a consciência do direito de si mesmo pelo restabelecimento da liberdade cristã. O princípio cristão passou pela tremenda disciplina da cultura, e pela Reforma lhes foram devolvidas a sua verdade e a sua realidade. Esse terceiro período vai da Reforma até nossos dias. O princípio do espírito livre tornou-se aqui o pendão do mundo, e a partir dele desenvolvem-se os principais fundamentos da razão. O pensamento formal, o entendimento, já estava formado, mas o pensamento só atingiu a sua verdadeira substância pela Reforma, pela renascida consciência concreta do livre espírito. Foi só então que o pensamento começou a sua formação; dele foram retirados fundamentos que serviram de base para a reconstrução da lei fundamental do Estado. A vida estatal efetivou-se, assim, com consciência conforme à razão. Costumes e origem não tinham mais valor, os diferentes direitos precisaram legitimar-se como baseados em princípios sensatos. Só assim a liberdade do espírito alcança a realidade. (ibid., p. 293).

Esse processo que determina o recíproco autonomizar-se das duas esferas leva ao desenvolvimento da religiosidade como escolha de liberdade interior, que da dimensão espiritual se traduz nas diferentes manifestações do pensamento, favorecendo o desenvolvimento do livre raciocínio, da ciência, da filosofia e da cultura. Ao mesmo tempo, isso favorece a vida do Estado, assim, suas regras jurídicas e formas institucionais se desenvolvem de forma coerente com os princípios da razão. Isso implica a suprassunção dos privilégios, das desigualdades jurídicas alicerçadas na particularidade, definida pelo nascimento e legitimada apenas pela tradição e os costumes. As regras administrativas, institucionais e jurídicas encontram seu fundamento apenas na racionalidade dos 
princípios, assim a liberdade do espírito alcança a realidade objetivando-se na racionalidade do Estado moderno.

A Reforma foi provocada pela profunda decadência da Igreja que, segundo Hegel, abrangia sua íntima essência $\mathrm{O}$ seja, não era um mero problema ocasional, fruto de abusos episódicos cuja responsabilidade estava nos erros, na corrupção ou no prevalecimento dos interesses particulares dos homens da Igreja, pelo contrário, tratava-se de uma crise bem mais profunda, orgânica e funcional que não simplesmente envolvia a instituição mesma, mas era imanente a ela. A decadência da Igreja, a primazia da mundanidade sobre a espiritualidade, que se encaminha quando ela não encontra mais nenhuma oposição, transformou o princípio eclesiástico em pura exterioridade, assim, a entidade que deveria salvar as almas da decadência fez dessa salvação um instrumento exterior:

A escravidão da autoridade, pois o espírito, havendo renunciado à própria natureza, não é livre, está preso fora de si; a crença em milagre, da maneira mais absurda e mais trivial, pois o divino é considerado de forma esporádica e finita, devendo existir para fins finitos e particulares; por fim, a ganância pelo poder, a luxúria e a devassidão, toda a perversidade da brutalidade e da infâmia, da hipocrisia e da fraude. Tudo isso encontra na Igreja, pois nela o sensível não é domado nem constituído pela razão; ele se tornou livre, mas só de forma rude e selvagem. Por outro lado, a virtude da Igreja, negativa só em oposição à temporalidade, é apenas abstratamente negativa. Ela não consegue ser moral na vida real e por isso é só fugida, resignada e inativa na realidade. (Ibid., p. 344).

Diante da magnificência das obras artísticas e dos orgulhosos monumentos arquitetônicos, realizados com o dinheiro dos cidadãos, o símbolo da exterioridade e do desejo de potência da Igreja, o genuíno espírito religioso cristão se conservou nos corações simples e despretensiosos dos alemães. Assim, quando todo o Ocidente estava voltado para a conquista das Índias Orientais e das Américas, foi um simples monge alemão o protagonista do distanciamento da exterioridade, até desnudar as contradições da Igreja, reconstruindo todos os ensinamentos e reformulando toda a superstição à qual a Igreja esatendeu (ibid., p. 345).

Lutero elabora sua doutrina diretamente nas Sagradas Escrituras, não atingindo apenas as crenças e superstições que se sobrepunham às obras. Uma vez suprimidas as relações de 
exterioridade, extingui-se também a separação entre sacerdote e leigo e uma casta sacerdotal que monopolize a exclusividade dos tesouros espirituais e da verdade já não é necessária. Nessa mudança, Hegel localiza a afirmação da liberdade subjetiva, que favorece uma outra progressão fundamental do espírito universal antes de realizar-se de forma absoluta no Estado constitucional:

É o coração, a espiritualidade sensível do homem, que pode e deve apoderar-se da verdade - essa subjetividade é a de todos os homens. Cada um deve realizar em si mesmo a obra de reconciliação. $\mathrm{O}$ espírito subjetivo tem que acolher o espírito da verdade em si e o abrigar. Aqui está a interioridade absoluta da alma, que pertence à religião e ganhou liberdade na Igreja. A subjetividade apodera-se agora do conteúdo objetivo, isto é, da doutrina da Igreja. Na Igreja luterana, a subjetividade e a certeza do indivíduo são tão necessárias quanto a objetividade da verdade. Para os luteranos, a verdade não é um objeto fabricado; é o próprio sujeito que deve tornar verdadeiro, ao desistir de seu conteúdo particular em troca da verdade substancial e apropriar-se dessa verdade. Dessa forma o espírito subjetivo torna-se livre na verdade, nega a sua particularidade e em sua verdade chega a si mesmo. Assim a liberdade cristã tornou-se real. Quando se coloca a subjetividade meramente no sentimento, sem esse conteúdo, permanece-se na mera vontade natural. Aqui se encontra o novo e último lema em torno do qual os povos se reúnem: a bandeira do espírito livre, que em si mesmo está na verdade - e só nela. Essa é a bandeira à qual servimos e que carregamos. Daquela época até nossos dias, nada mais se realizou ou deve se realizar a não ser cultivar esse princípio no mundo - já que a reconciliação em si e a verdade também se tornam objetivas, segundo a forma. Até a cultura pertence à forma; a cultura é a confirmação da forma universal, e isso é o próprio pensamento. $\mathrm{O}$ direito, a propriedade, a moralidade objetiva, o governo e a constituição, entre outras coisas, têm agora que ser determinados de maneira universal para que sejam adequados e razoáveis ao conceito de livre vontade. Só assim o espírito da verdade pode surgir na vontade subjetiva, na atividade particular da vontade. Se a intensidade do livre espírito subjetivo decide-se pela forma da universalidade, então o espírito objetivo pode se manifestar. Nesse sentido, é preciso compreender que o Estado foi constituído na religião. Estados e leis não são mais do que o surgimento da religião nas relações da realidade. Este é o conteúdo essencial da Reforma: o homem está determinado por si mesmo a ser livre. (Ibid., p. 346). 
A Reforma favoreceu o desenvolvimento e o progresso do espírito, determinando também uma nova, relação mais harmônica (Hegel fala explicitamente de reconciliação), entre esfera espiritual e esfera temporal, emancipando a primeira do vínculo com asegundo e vice-versa.

Essa reconciliação do Estado e da Igreja foi espontânea, embora ainda não possamos falar de uma estrutura institucionalmente articulada e sistematicamente organizada, o justo se encontra na dimensão do pensamento. Ao longo do processo histórico abordado por Hegel, como já esclarecido, a Reforma luterana assume um valor central no processo de afirmação da liberdade, impondo o valor da interioridade como libertação religiosa contra a pretensão do poder temporal. O critério absoluto contra toda a autoridade da fé religiosa, das leis positivas, do direito, conseguiu compreender "o conteúdo do próprio espírito em livre presencia" (ibid., p. 361).

Sendo a razão o fundamento substancial tanto da consciência como do exterior e do natural, a rígida divisão entre interesse teórico e interesse prático desaparece; nessa conciliação, onde "o pensamento é agora o estágio a que o espírito chegou", reside a mola do grande progresso das ciências. "O espírito reconhece que a natureza, o mundo precisa ter uma razão na existência", assim surge interesse universal para o conhecimento do mundo moderno que leva à idade do iluminismo:

O universal na natureza são as espécies, os gêneros, a força e o peso, reduzidos às suas manifestações. Assim, a experiencia tornou-se ciência do mundo, pois ela é, por um lado, a percepção, mas também o descobrimento da lei, do interior, da força, ao devolver o existente à sua simplicidade [...]. Abriram-se os olhos dos homens, o sentido foi provocado, e o pensamento passou a trabalhar e a se esclarecer. As grandes superstições da época depararam-se com as leis da natureza, assim como todas as representações de poderosas forças estranhas que só poderiam ser derrotadas com a magia. Em toda parte, falava-se a respeito disso, não só entre os católicos, mas também entre os protestantes. O exterior que a Igreja quer relacionar com o sublime é meramente exterior, assim como a hóstia é só trigo, e as relíquias, só ossos. Contra essa fé na autoridade foi imposto o domínio do sujeito por si mesmo, e as leis naturais foram reconhecidas como a única ligação do exterior com o exterior. Assim, todos os milagres foram contestados, pois a 
natureza é um sistema de leis conhecidas e reconhecidas [...] A essas determinações universais, baseadas na consciência presente, nas leis da natureza e em seu conteúdo que é justo e bom, chamouse de razão; à validade dessas leis chamou-se de iluminismo. (Ibid., p. 361-362).

O processo se desenvolve a partir da dimensão teórica e abstrata dos princípios universais, para chegar, depois de ter superado dialeticamente, no plano racional, as cristalizações das concepções dogmáticas, ao revolucionamento da realidade concreta com suas regras e instituições:

Esse princípio do pensamento surge, inicialmente, em sua universalidade ainda abstrata e repousa no fundamento da contradição e da identidade. O conteúdo é, com isso, posto como finito, e toda a especulação das coisas humanas e divinas é banida e exterminada pelo iluminismo. Se é infinitamente importante que a forma variada seja trazida para a sua simples determinação, sob a forma da universalidade, então esse princípio ainda abstrato não basta ao espírito vivo, à alma concreta. Com esse princípio formalmente absoluto chegamos ao último estágio da história, ao nosso mundo, aos nossos dias. A mundanidade é o reino espiritual na existência, o reino da vontade que se torna existência. (Ibid., p. 363)

Depois da negação da autoridade eclesiástica e a sua defensa pelo Concílio de Trento, a unidade da cristandade ficou impossível: por um lado, nos países reformados, bispados, conventos e outras instituições católicas, como aquelas da educação, foram suprimidas, assim como o que ficava do poder temporal da Igreja; por outro, a Igreja católica tentou segurar sua rede e articulação eclesial, mas, ao mesmo tempo, aviou um processo de reforma, embora tudo o que ficou fora de seus princípios tenha sido condenado e "ingenuamente" perseguido. Isso teve o efeito de travar o desenvolvimento do catolicismo e determinou sua definitiva separação em relação ao novo desenvolvimento do pensamento científico. O protestantismo, em contrapartida, favoreceu esse desenvolvimento sem entrar em contradição com o surgimento do próprio iluminismo.

A Igreja parou: "Somente até aqui e nada mais!" Ela se separou da florescente ciência e da literatura humanista, e logo teve oportunidade de exprimir sua repugnância pela ciência. O célebre Copérnico descobriu que a Terra e os planetas giravam em torno do sol, mas a Igreja declarou-se contrária a esse progresso. Galileu, 
numa discussão sobre as razões favoráveis ou desfavoráveis dessa nova descoberta de Copérnico, declarando-se ele mesmo favorável, foi obrigado, de joelhos, a pedir perdão por essa calúnia. A literatura grega não se tornou o fundamento da cultura, e a educação foi entregue aos jesuítas. Dessa forma sucumbe o espírito do mundo católico. (Ibid., p. 348).

Concluindo esse longo aprofundamento complementar, Hegel, na sua descrição filosófica da afirmação da moderna sociedade burguesa, compreende que o processo de secularização torna mais forte o espírito religioso, transformado em interioridade e trazido para a esfera da individualidade, que encontra sua completa soberania na sociedade civil; ao mesmo tempo, fortalece o Estado, que não precisa mais da legitimação religiosa para afirmar sua dimensão ética perante os cidadãos. É exatamente essa a argumentação utilizada por Marx em sua polêmica com Bauer, para explicar como a emancipação política não corresponde ao fim da religião, tampouco à completa emancipação do homem, porque não é a religião a verdadeira essência do Estado.

Pelo contrário, ele reafirma que a emancipação política da religião a deixa sobreviver, ainda que não como religião privilegiada. A emancipação política leva apenas à superação de uma parte da contradição secular entre Estado político e sociedade burguesa vivida pelo crente de uma determinada religião em relação à sua condição de cidadania. A perfeição do Estado cristão é o Estado que abstrai a religião de seus cidadãos, mas a emancipação do Estado da religião não é a emancipação do homem real da religião.

Não estamos, portanto, dizendo aos judeus, como faz Bauer: vós não podeis vos tornar politicamente emancipados sem vos emancipar radicalmente do judaísmo. Estamos lhes dizendo, antes: pelo fato de poderdes vos emancipar politicamente sem vos desvincular completa e irrefutavelmente do judaísmo, a emancipação política não é por si mesma a emancipação humana. Se vós, judeus, quereis vos emancipar politicamente sem vos emancipar em termos humanos, então a parcialidade e a contradição não se acham apenas em vós, mas também na essência e na categoria da emancipação política. (MARX, 2010, p. 46). 


\section{Liberdade formal e igualdade social}

Segundo Bauer, escreve Marx, o homem deve renunciar ao privilégio da fé se quiser obter os direitos humanos universais que se afirmaram com a Revolução Americana e com a Revolução Francesa, ou seja os direitos políticos (a liberdade de opinião e o direito de participação na vida da comunidade, como cidadão ativo e sujeito de direito), e a liberdade de consciência, que dizer, o direito de praticar qualquer culto. Tanto na Declaração dos direitos do homem $e$ do cidadão, da Revolução Francesa, quanto nos princípios constitucionais norte-americanos, a emancipação política dos chamados direitos humanos não estaria em contradição com a profissão religiosa, pelo contrário, o privilégio da fé se torna um dos direitos fundamentais do homem.

A afirmação dos princípios dos direitos humanos, caraterísticos das revoluções burguesas, representa um grande progresso na história da humanidade, todavia, Marx sublinha a natureza puramente formal dos conceitos de liberdade e igualdade que se afirmaram. A questão social mostrou a contradição entre duas concepções de justiça: a igualdade formal, dos cidadãos diante da lei; a igualdade substancial, pela qual a permanência do privilégio e das profundas diferenças econômico-sociais é um limite insuperável para a efetiva possibilidade de exercer o primeiro direito. Assim, Marx escreve que nenhum dos direitos humanos vai além do homem egoísta, do homem enquanto membro da sociedade civil, ou seja, do indivíduo voltado para si mesmo, em sua dimensão privada, separada da comunidade. Trata-se do homem da liberdade negativa, como intangibilidade da esfera individual privada por parte do Estado. Na visão liberal da liberdade, o principal problema é limitar o poder do Estado, por meio de uma estrutura constitucional que freie sua tendência expansionista, limitando a esfera de sua intervenção ao mínimo possível para deixar todo o restante à iniciativa privada: um Estado gendarme que vigia os equilíbrios espontâneos gerados pelo mercado. A liberdade se configura como direito de fazer e empreender tudo aquilo que não prejudique os outros, o direito do homem à liberdade não é fundado sobre a união do homem com o homem, mas baseia-se na separação do homem em relação a seu semelhante. Assim, a liberdade é o direito do indivíduo delimitado, limitado a si mesmo. 
Muito longe de conceberem o homem como um ente genérico, esses direitos deixam transparecer a vida do gênero, a sociedade, antes como uma moldura exterior ao indivíduo, como limitação de sua autonomia original. O único laço que os une é a necessidade natural, a carência e interesse privado, a conservação de sua propriedade e de sua pessoa egoísta. (Ibid., p. 50). Os chamados direitos humanos nada mais são do que direitos do membro da sociedade burguesa, isto é, do homem egoísta e separado da comunidade. A dimensão prática da liberdade do homem é o direito à propriedade privada, que Marx, comentando o Artigo 16 da Constituição de 1793, assim define:

O direito humano à propriedade privada, portanto, é o direito de desfrutar a seu bel prazer (à son gré), sem levar outros em consideração, independentemente da sociedade, de seu patrimônio e dispor sobre ele, é o direito ao proveito próprio. Aquela liberdade individual junto com esta sua aplicação prática compõem a base da sociedade burguesa. Ela faz com que cada homem veja no outro homem, não a realização, mas, ao contrário, a restrição de sua liberdade. (Ibid., p. 49). A emancipação política avançada por Bauer não questiona minimamente esse quadro geral do direito do homem egoísta, ou seja, do homem burguês, mas, pelo contrário, fortalece sua dimensão separada que impede a efetiva e integral emancipação humana.

Esse fato se torna ainda mais enigmático quando vemos que a cidadania, a comunidade política, é rebaixada pelos emancipadores à condição de mero meio para a conservação desses assim chamados direitos humanos e que, portanto, o citoyen é declarado como serviçal do homme egoísta; quando vemos que a esfera em que o homem se comporta como ente comunitário é inferiorizada em relação àquela em que ele se comporta como ente parcial; quando vemos, por fim, que não o homem como citoyen, mas o homem como bourgeois é assumido como o homem propriamente dito e verdadeiro. (Ibid., p. 50, grifos do original).

Na concepção da Constituição de 1793, e do próprio Bauer, a vida política acaba por ser meramente um instrumento que tem por tarefa e fim a vida e a defesa da sociedade civil. $\mathrm{Na}$ afirmação histórica da burguesia, a emancipação política é, ao mesmo tempo, a dissolução da velha sociedade aristocrático-feudal, acima da qual se elevava o poder absoluto do monarca. A revolução política é a revolução da sociedade civil que afirma sua 
esfera de autonomia do poder político esvaziando a antiga articulação corporativa da sociedade civil feudal da sua função política. Nessas linhas, Marx retoma algumas das argumentações utilizadas na Crítica da filosofia do direito, em polêmica com o "anacronismo de Hegel", para descrever o processo que leva a burguesia a revolucionar todo o sistema das relações políticas com a radical transformação das relações sociais de produção. Como já havia explicado no texto de 1843, Marx reafirma que a velha sociedade civil tinha um caráter imediatamente político, ou seja, suas componentes, a propriedade privada, a família e o trabalho, no contexto da propriedade fundiária feudal, das camadas e das corporações, assumiam o significado de elementos da vida do Estado. A relação do indivíduo com a autoridade estatal era determinada pelo pertencimento a esses organismos intermediários, que desenhavam um quadro marcado por sociedades particulares no interior da sociedade feudal, por isso chamada sociedade de "castas fechadas". Assim, as funções e as condições de vida da sociedade civil tinham caráter político, ainda que político no sentido feudal. Essas articulações excluíam o indivíduo da totalidade estatal, transformando a relação particular de sua corporação com o Estado na própria relação universal para a vida do povo, como transformavam sua atividade e situação civil específica em sua atividade e situação universal. A revolução política da burguesia derrubou esse poder do monarca absoluto, elevando os negócios do Estado a negócios do povo, criando o Estado político como entidade universal, ou seja, um Estado que abolia as camadas, as corporações e os privilégios que representavam a fragmentação particular da sociedade feudal, suprimindo o caráter político da sociedade civil:

Ela decompôs a sociedade burguesa em seus componentes mais simples, ou seja, nos indivíduos, por um lado, e, por outro, nos elementos materiais e espirituais que compõem o teor vital, a situação burguesa desses indivíduos. Ela desencadeou o espírito político que estava como que fragmentado, decomposto, disperso nos diversos becos sem saída da sociedade feudal; ela o congregou a partir dessa dispersão, depurou-o da sua mistura com a vida burguesa e o constituiu como a esfera do sistema comunitário, da questão universal do povo com independência ideal em relação àqueles elementos particulares da vida burguesa. A atividade vital específica e a situação vital específica foram reduzidas a uma importância apenas individual. Elas não mais constituíam a relação universal do indivíduo com a totalidade do Estado. A questão pública como tal 
se tornou, antes, a questão universal de cada indivíduo e a função política se tornou uma função universal. (Ibid., p. 52).

A consagração do idealismo do Estado, como entidade acima das partes com a função de afirmar o universal em harmonia com o interesse particular, representou, ao mesmo tempo, a consagração do materialismo da sociedade civil. A destruição do poder feudal foi simultaneamente a eliminação das amarras que prendiam o individualismo da sociedade civil. Assim, segundo Marx, a emancipação política foi, ao mesmo tempo, a emancipação da sociedade civil da política, da aparência de um seu conteúdo universal. O indivíduo egoísta e atomizado, desvinculado da arregimentação corporativa, é agora o pressuposto do Estado político, que o reconhece como tal afirmando a esfera dos direitos individuais dos homens onde o poder não pode intervir.

Consequentemente o homem não foi libertado da religião. Ele ganhou a liberdade de religião. Ele não foi libertado da propriedade. Ele ganhou a liberdade de propriedade. Ele não foi libertado do egoísmo do comércio. Ele ganhou a liberdade de comércio. (Ibid., p. 53). A afirmação da sociedade burguesa representa uma profunda revolução econômica, social e política, assim, a constituição do Estado político e a dissolução da sociedade civil na dimensão independente da individualidade, garantida pelo direito, acontece no mesmo momento em um único ato. Se trata claramente de uma mudança radical determinada por exigências racionais e interesses da nova classe surgida da decomposição da sociedade feudal; todavia, o homem independente da sociedade civil (uma absoluta novidade) é apresentado como homem natural, e os direitos humanos (mesmos inéditos) são definidos direitos naturais. É exatamente essa separação que antepõe o interesse particular, acima do qual se articulam as relações sociais, jurídicas, institucionais e as representações filosóficas, que impede a emancipação humana.

A emancipação política é a redução do homem, por um lado, a membro da sociedade burguesa, a indivíduo egoísta independente, e, por outro, a cidadão, a pessoa moral.

Mas a emancipação humana só estará plenamente realizada quando o homem individual real tiver recuperado para si o cidadão abstrato e se tornado ente genérico na qualidade de homem individual na sua vida empírica, no seu trabalho individual, nas suas relações individuais, quando o homem tiver reconhecido e organizado suas 
"forces propres" [forças próprias] como forças sociais e, em consequência, não mais separar de si mesmo a força social na forma da força política. (Ibid., p. 54).

Marx levanta a necessidade de superar a formulação teológica da questão judaica para chegar ao coração da contradição que determina a alienação do homem na sociedade moderna. A capacidade de emancipação do judeu reside na relação do judaísmo com a emancipação do mundo de hoje, não com a simples emancipação do Estado em relação à religião. Sobre a questão judaica é um divisor de águas no processo da formação intelectual de Marx, em que a dialética entre a alienação e a emancipação humana torna-se um dos temas centrais de toda a sua obra.

\section{Conclusões}

O conjunto de questões levantadas pela reflexão do jovem Marx mantém o valor de uma crítica incrivelmente eficaz aos limites da sociedade burguesa. Para compreender plenamente seu valor, entretanto, é necessário colocar textos como esse em sua dimensão, como etapa inicial em um longo percurso de esclarecimento intelectual, e não como revelação de uma verdade final já contida em sua formulação inicial. A teoria de Marx é fruto de um processo de amadurecimento intelectual no qual eventos políticos, estudos econômicos e a simples observação da vida real influenciaram profundamente e tornaram bem mais complexa sua visão das coisas. Como salientado por Musto, ter plena consciência disso é muito importante, porque significa colocar na devida dimensão alguns escritos juvenis, muitas vezes incompletos ou nunca publicados, outras vezes considerados totalmente representativos de suas teses mais significativas. (MUSTO, 2019a, p. 40-41).

Por sua vez, Stefano Petrucciani nos assinalou que o estudo do pensamento de Marx impõe requisitos metodológicos precisos, capazes de escapar dos limites das leituras que, durante o século XX, tornaram-se predominantes nas investigações marxistas. $\mathrm{O}$ teórico do materialismo histórico certamente foi analisado por grandes autores, como Lukács e Althusser, mas muitas vezes o resultado dessa análise provou ser mais útil para entender o pensamento desses intérpretes do que para colocar Marx em sua dimensão correta. Para aproveitar ao máximo o legado teórico marxiano, a abordagem dos estudos de seu trabalho 
deve ser inspirada, segundo Petrucciani, em três adjetivos: "crítico, livre e comprometido". A crítica, em particular, assume uma importância central para se relacionar com um autor que muitas vezes foi descartado sem que seus detratores tenham estudado ou sequer lido sua obra. Mas a criticidade também serve para evitar, ao contrário, a monumentalização que tornou Marx objeto de um culto quase religioso, incapaz de ir além da simples apologia e dos tons encomiásticos da liturgia comemorativa.

Esse tipo de discussão sobre Marx (a dos marxistas e também a dos antimarxistas) constituiu sem dúvida uma parte importante do debate ideológico e cultural do século XX; mas foi uma discussão demasiado quente, demasiado incandescente, para ser verdadeiramente científica; e foi, além disso, uma discussão que, após a queda do Muro de Berlim e o fim dos grandes partidos comunistas, aparece hoje definitivamente ultrapassada. (PETRUCCIANI, 2014, tradução nossa).

Para evitar os dois desvios, Marx deveria ser estudado como "uma peça importante da história do pensamento ocidental", isso significa estudá-lo de forma mais científica, liberando a leitura das paixões excessivas (em registro positivo ou negativo) com o mesmo desprendimento reservado aos grandes autores das doutrinas filosóficas. Certamente Marx fala ao mundo de hoje muito mais do que autores clássicos como Hobbes ou Kant, portanto, a tentativa de mostrar a atualidade de seu pensamento não pode ser simplesmente negada, no entanto, essa necessidade não deve obscurecer a necessidade da abordagem crítica e científica no passado muitas vezes ofuscada pelas paixões contrapostas. Além disso, Petrucciani conclui, a fim de compreender o mundo contemporâneo com suas contradições, talvez seja mais útil aprofundar os problemas teóricos imanentes ao raciocínio de Marx do que insistir na validade de suas predições. Um dos maiores meritos de Marx consiste em ter tentado dar ao pensamento crítico uma forma científica ao tomar posse de todo o conhecimento mais avançado. É precisamente a cientificidade do método crítico de Marx que não admite absolutização apologética por parte de seus estudiosos e intérpretes; portanto, além de valorizar suas grandes aquisições, é necessário lidar com os grandes "nós não resolvidos" de sua doutrina. Assumir essa perspectiva não significa limitar o valor atual do pensamento de Marx, mas encontrar a tradução de suas categorias dentro de uma realidade que, sendo dialética, nunca 
permanece igual a si mesma e sempre se relaciona dialeticamente com a natureza transeunte e contraditória da concretude social. 


\section{REFERÊNCIAS}

BAUER, B.; MARX, K. La questione ebraica. Organização M. : Tomba. Roma: Manifestolibri, 2004.

DONAGGIO, E. I manoscritti economico-filosofici del 1843-44. In: PETRUCCIANI, S. (Org.). Il pensiero di Karl Marx. Filosofia, politica, economia. Roma: Carocci, 2018.

GIDDENS, A. Capitalismo e teoria sociale. Marx, Durkheim e Max Weber. Milão: Mondadori, 1991.

HEGEL, G. W. F. Filosofia da história. Tradução: Maria Rodrigues e Hans Harden. Brasília: Editora UnB, 1995.

MARX, K. Sobre questão judaica. Tradução: Nélio Schneider. São Paulo: Boitempo, 2010.

Schneider, Luciano

; ENGELS, F. A ideologia alemã. Tradução: Rubens Enderle, Nélio

Cavini Martorano. São Paulo: Boitempo, 2007.

MCLELLAN, D. La concezione materialistica della storia. In: MCLELLAN, D. Storia del marxismo. Il marxismo ai tempi di Marx. Turim: Einaudi, 1978. v. 1.

MOGGAH, D. The Philosofy and Politics of Bruno Bauer. Cambridge: Cambridge University Press, 2003.

MUSTO, M. Karl Marx. Biografia intellettuale e politica. Turim: Einaudi, 2018a. . Comunismo In: MUSTO, M. Marx revival. Concetti essenziali e nuove letture. Roma: Donzelli, 2019a. . L'ultimo Marx. 1881-1883. Roma: Donzelli, 2016. (Org.). Marx revival. Concetti essenziali e nuove letture. Roma: Donzelli, $2019 b$. . O velho Marx: uma biografia de seus últimos anos (1881-1883). Tradução: Rubens Enderle. São Paulo: Boitempo, 2018 b.

PETRUCCIANI, S. A lezione da Marx. Castel San Pietro Romano, Manifestolibri, 2014. E-book. (Primeira parte, "Marx oggi", cap. 1, "Come leggere Marx oggi", parágrafo 1, "Questioni di metodo"). 
Marx. Roma: Carocci, 2009.

RAWLS, J. O liberalismo politico. Tradução: Dinah de Abreu Azevedo. 2. ed. São Paulo: Ática, 2000.

ROSEN, Z. Bruno Bauer and Karl Marx. Amsterdã: International Institute of Social History, 1977.

WOOD, E. M. Democrazia. In: MUSTO, M. Marx revival. Concetti essenziali e nuove letture. Roma: Donzelli, 2019. 